\title{
Virgin Coconut Oil as Oil Phase in Tretinoin Nanoemulsion by Tristiana Erawati
}

Submission date: 01-Mar-2019 11:42AM (UTC+0800)

Submission ID: 1085773272

File name: Virgin_Coconut_Oil_as_Oil_Phase_in_Tretinoin_Nanoemulsion.pdf (194.81K) Word count : 1564

Character count: 8115 
Available online on www.ijddt.com

International Journal of Drug Delivery Technology 2017; 7(1); 42-44

doi: $10.25258 /$ ijddt.v7i1.8915

ISSN: 09754415

Research Article

\title{
Virgin Coconut Oil as Oil Phase in Tretinoin Nanoemulsion
}

\author{
Tristiana Erawati M*, Retnowati, Amalia Wardatul F, Widji Soeratri \\ Pharmaceutics Department of Faculty of Pharmacy, Airlangga University, Kampus B UNAIR, Jl Dharmawangsa Dalam \\ Surabaya, 60286.
}

Received: 15 $5^{\text {th }}$ Nov, 2016; Revised: $21^{\text {st }}$ Jan, 2017; Accepted: $3^{\text {rd }}$ Feb, 2017; Available Online: $1^{\text {st }}$ March, 2017

\begin{abstract}
This study was aimed to determine the characteristic and tretinoin release in nanoemulsion using virgin coconut oil (VCO) as oil phase compared with emulsion. The characteristics of the tretinoin nanoemulsion (TN) were observed in terms of droplet morphology by Transmission Electron Microscopy (TEM) and droplet size by particle analyzer and light microscope and the $\mathrm{pH}$ value by $\mathrm{pH}$ meter. The release rate of tretinoin in nanoemulsion and emulsion was measured by Franz diffusion cell using cellophane membrane. Result of this research showed the droplet morphology of tretinoin nanoemulsion and emulsion were spherical. The droplet size of tretinoin nanoemulsion $(72.57 \pm 18.16 \mathrm{~nm})$ was smaller than tretinoin emulsion $(10.54 \pm 0.61 \mu \mathrm{m})$. The $\mathrm{pH}$ value of tretinoin nanoemulsion and tretinoin emulsion was $6.24 \pm$ 0.01 and $6.21 \pm 0.02$. In interval times $5-60$ minutes the tretinoin release rate (flux) in nanoemulsion was $0.158 \pm 0.016$ $\mu \mathrm{g} / \mathrm{cm}^{2} /$ minute higher than in emulsion which was $0.048 \pm 0.016 \mathrm{~g} / \mathrm{cm}^{2} /$ minute. In interval times $60-180$ minutes, tretinoin release rate (flux) in nanoemulsion was $0.046 \pm 0.005 \mathrm{~g} / \mathrm{cm}^{2} /$ minute lower than in emulsion which was $0.090 \pm$ $0.016 \mathrm{~g} / \mathrm{cm}^{2} /$ minute. In interval times $180-720$ minutes the tretinoin release rate (flux) in nanoemulsion was $0.025 \pm$ $0.001 \mathrm{~g} / \mathrm{cm}^{2} /$ minute which had no significant different compared to in emulsion which was $0.022 \pm 0.002 \mathrm{~g} / \mathrm{cm}^{2} / \mathrm{minute}$. The statistical analysis of the tretinoin release rate value using independent $\mathrm{T}$-test result was known that there were significant different between nanoemulsion (TN) and emulsion (TE). Conclusion: The droplet size of tretinoin nanoemulsion was below $100 \mathrm{~nm}, \mathrm{pH}$ value $6.24 \pm 0.01$ and the tretinoin release rate in nanoemulsion using VCO was higher than in emulsion.
\end{abstract}

Keywords: Characterization, Nanoemulsion, Release rate (Flux), Virgin Coconut Oil (VCO), Tretinoin

\section{INTRODUCTION}

Virgin coconut oil (VCO) is one of vegetables oil that used as oil phase in nanoemulsion. In the previous study nanoemulsion using VCO produced droplet size smaller than nanoemulsion using corn oil and soybean oil. ${ }^{1}$ Smaller droplet size caused rapid drug release that can increase penetration into the skin. Nanoemulsion also known can increase solubility of drug. In this research VCO used in nanoemulsion for delivery system of Tretinoin an antiaging, ${ }^{2,3}$ it was practically insoluble in water. Tretinoin nanoemulsion using $\mathrm{VCO}$ was than characterized and tested on the tretinoin release compared with tretinoin in emulsion.

\section{MATERIAL AND METHODS}

Research Materials

Tretinoin (PT. Cortico Mulia), virgin coconut oil (VCO), Tween 80 (Sigma Aldrich), Span 80 (Sigma Aldrich), ethanol $96 \%$ (E-Merck), NaH2PO4 (E-Merck) and Na2HPO4 (E-Merck), aquademineralisata (PT Brataco), Methanol (E-Merck)

Research Instruments

Stirrer plate (Dragon Lab MS-Pro), ultrasonic (Branson 3510), shaker machine (Wine shake), $\mathrm{pH}$ meter (Eutech Instruments $\mathrm{pH} 700$ ), particle analyzer (Delsa Nano C), Franz diffusion cell with cellophane membranes, spectrophotometer (Shimadzu UV-1800), Transmission Electron Microscopy (TEM-type JOEL JEM-1400), light microscope.

Methods

Nanoemulsion and emulsion preparation:

Nanoemulsion and emulsion preparation was done by Erawati and Soeratri method. ${ }^{4}$ Formulas tretinoin nanoemulsion (TN) and tretinoin emulsion (TE) was presented in Table 1. The tretinoin nanoemulsion was characterized included; $\mathrm{pH}$, droplet morphology by TEMtype JOEL JEM-1400, droplet size and polydispersity index by particle analyzer Delsa Nano $\mathrm{C}$. The tretinoin emulsion characterized included; $\mathrm{pH}$, droplet morphology and droplet size by light microscope.

Release Study

A cellophane membrane was immersed in water for \pm 12 hours. It was drained until no water is drip $3 \mathrm{hg}$ before used, and then was mounted on the su 2 ce of the receptor compartment of Franz diffusion cell. Franz diffusion cell Receptor compartment was filled with phosphate buffer medium pH $6.0 \pm 0.2$ up to full (temperature $32 \pm 2^{\circ} \mathrm{C}$, at $100 \mathrm{rpm})$. Then, $2 \mathrm{ml}$ of tretinoin nanoemulsion or tretinoin emulsion was inserted into the donor compartment. Samples $(1 \mathrm{ml})$ were taken within a certain time interval, i.e. at $0,5,10,15,30,45$ minutes, and then $1,1.5,2,3,4,6,8,10,12$ hours. Immediately after

*Author for Correspondence: era_ffua@yahoo.co.id 


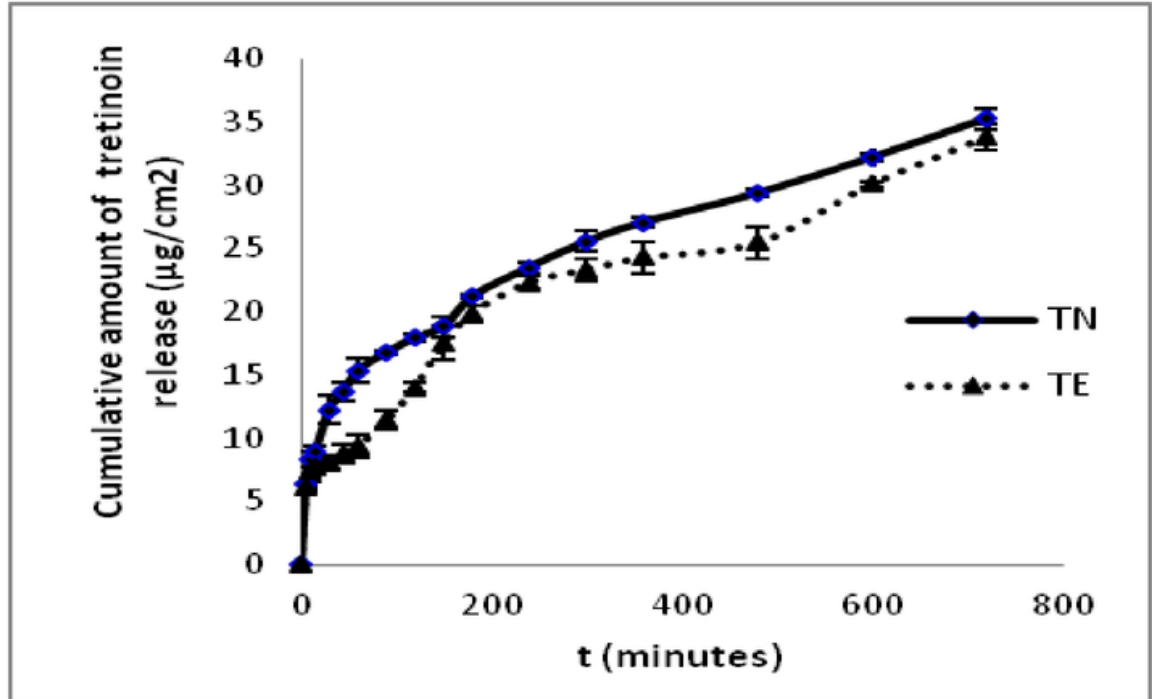

Figure 1: Release profile of tretinoin in nanoemulsion (TN) and in emulsion (TE).

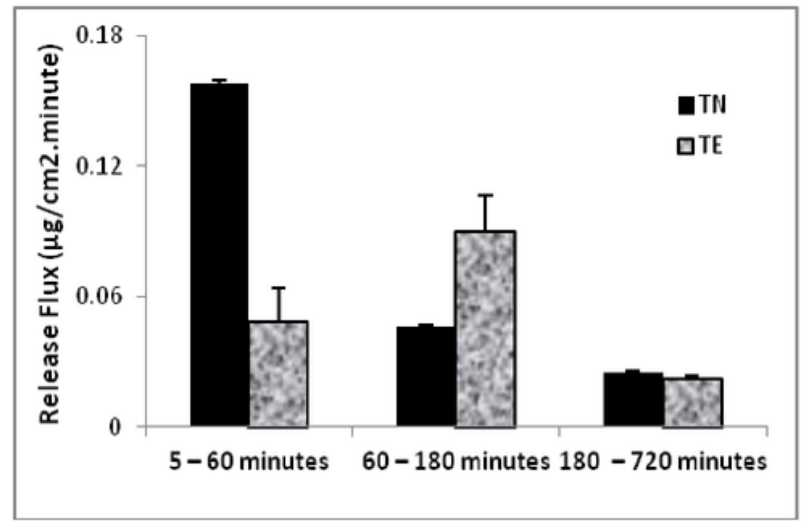

Figure 2: Histogram release flux of tretinoin in nanoemulsion (TN) and in emulsion (TE) in interval times 5-60, $60-$ 180 and $180-720$ minutes.

Table 1: Formula of Tretinoin in Nanoemulsion (TN) and Emulsion (TE) using VCO as oil phase.

\begin{tabular}{lll}
\hline \multirow{2}{*}{ Materials } & \multicolumn{2}{l}{ Concentration $(\%)$} \\
\cline { 2 - 3 } & TN & TE \\
\hline Tretinoin & 0.1 & 0.1 \\
1CO & 2.66 & 1,66 \\
Span 80 & 1.92 & 14,17 \\
Tween 80 & 18.66 & 6,40 \\
Ethanol 96\% & 3.42 & - \\
Phosphate buffer & ad 100 & ad 100 \\
solution pH $6.0 \pm 0.5$ & & \\
\hline
\end{tabular}

sampling medium was replaced with phosphate buffer $\mathrm{pH}$ $6.0 \pm 0.2$ with a volume of samples taken. Subsequently, samples were taken and were observed with UV-Vis spectrophotometer. Tretinoin concentration in the sample was calculated using the standard curve regression equation, then correction to the measured concentration using the Wurster equation.
Table 2: Characteristics of Tretinoin Nanoemulsion (TN) and Treninoin Emulsion (TE).

\begin{tabular}{lll}
\hline Characteristic & TN & TE \\
\hline $\mathrm{pH}$ & $6.29 \pm 0.01$ & $6.21 \pm 0.015$ \\
Droplet size & $85.53 \pm 6.28 \mathrm{~nm}$ & $11.70 \pm 2.51 \mu \mathrm{m}$ \\
Polidispersity & $0.676 \pm 0.05$ & - \\
Index & & \\
\hline
\end{tabular}

\section{RESULT AND DISCUSSION}

The characteristics of tretinoin nanoemulsion (TN) and tretinoin emulsion (TE) included $\mathrm{pH}$, droplet size and polidispersity index was presented in Table 2 . The $\mathrm{pH}$ value of both nanoemulsion and emulsion tretinoin were in the range of $\mathrm{pH}$ skin, it was expected that would not cause irritation when used.

Tretinoin nanoemulsion droplet size was about $85.53 \pm$ $6.28 \mathrm{~nm}$; it was smaller than tretioin emulsion droplet size of $11.70 \pm 2.51 \mu \mathrm{m}$ (Table 2). Droplet morphology of 
Table 3: Release Flux of Tretinoin Nanoemulsion (TN) and Tretinoin Emulsion (TE) in interval times 5 $-60,60-180$ and $180-720$ minutes.

\begin{tabular}{|c|c|c|c|}
\hline \multirow{2}{*}{ Sample } & \multicolumn{3}{|c|}{$\begin{array}{l}\text { Release Flux in interval times (minutes) } \\
\text { mean } \pm \mathrm{SD}\left(\mu \mathrm{g} / \mathrm{cm}^{2} \cdot \text { minute }\right)\end{array}$} \\
\hline & $5-60$ & $60-180$ & $180-720$ \\
\hline TN & $\begin{array}{c}0.158 \\
0.016\end{array}$ & ${ }^{ \pm} 0.046 \pm 0.005$ & $0.025 \pm 0.001$ \\
\hline TE & $\begin{array}{c}0.048 \\
0.016\end{array}$ & $\begin{array}{l} \pm .090 \\
0.016\end{array}$ & $0.022 \pm 0.002$ \\
\hline
\end{tabular}

tretinoin nanoemulsion by TEM and tretinoin emulsion by light microscope both was appeared spherical. The release profiles of tretinoin in nanoemulsion (TN) and in emulsion (TE) were presented in Figure 1 and the tretinoin release-rate (Flux) in nanoemulsion and emulsion was presented in Table 3 and Figure 2. From the release profile it was known that there were three interval times that gave different release rate (Flux). In first five minutes, the amount of tretinoin release from nanoemulsion (TN) and emulsion (TE) was equal; it may be caused by tretinoin existing in the water phase. From 5 to 60 minutes tretinoin release rate (Flux) from nanoemulsion (TN) was $0.158 \pm 0.016 \mu \mathrm{g} / \mathrm{cm}^{2} /$ minute, higher than in emulsion (TE) is $0.048 \pm 0.016$ $\mathrm{g} / \mathrm{cm}^{2} /$ minute. It can caused by droplet size of tretinoin nanoemulsion was smaller than tretinoin emulsion so it more rapid to release. In the second interval times (from 60 to 180 minutes) tretinoin release rate (flux) from nanoemulsion (TN) is $0.046 \pm 0.005 \mathrm{~g} / \mathrm{cm}^{2} /$ minute lower than in emulsion (TE) is $0.090 \pm 0.016 \mathrm{~g} / \mathrm{cm}^{2} /$ minute, it can caused by concentration tretinoin in nanoemulsion became lower than in emulsion. In the third interval times (from 180 to 720 minutes) tretinoin release rate (flux) in nanoemulsion is $0.025 \pm 0.001 \mathrm{~g} / \mathrm{cm}^{2} /$ minute had no significant different with in emulsiol 1 which was $0.022 \pm$ $0.002 \mathrm{~g} / \mathrm{cm}^{2} /$ minute. The result of statistical analysis by independent T-test with degree of confident $95 \%(\alpha=$ 0.05 ), known that release-rate (Flux) tretinoin in nanoemulsion was higher than in emulsion.

\section{CONCLUSION}

The conclusion of this study is tretinoin nanoemulsion using virgin coconut oil (VCO) produced droplet sizes below $100 \mathrm{~nm}$, the $\mathrm{pH}$ value $6.24 \pm 0.01$ and the value of tretinoin release rate in nanoemulsion was higher than in the emulsion

\section{ACKNOWLEDGEMENT}

The authors want to thank Indonesia Government who gives research fund through Airlangga University and Faculty of Pharmacy Airlangga University.

\section{REFERENCES}

1. Erawati T. Hendradi E., Soeratri W., Praformulation Study Of $p$-Methoxycinnamic Acid (APMS) Nanoemulsion Using Vegetable Oils (Soybean Oil, Corn Oil, VCO), Int. J Pharm. Pharm. Sci., Vol. 6, Issue 2, 2014, p 99-101.

2. Kligman AM, Grove GL, Hirose R, et al., Topical tretinoin for photo aged skin, $J$ Am Acad. Dermatology; 15: 1986, p 836-859.

3. Stefanaki C, Stratigos A, Katsambas A., Topical retinoids in the treatment of photoaging, Journal of Cosmetic Dermatology, July 2005, 4, 2005, p $130-$ 134.

4. Erawati T. and Soeratri W., Characterization and the Release Test of Anti-Aging Tretinoin in Nanoemulsion Using Olive Oil, International conference on Medicines and Health Sciences, 2016, Jember University, Indonesia. 
Virgin Coconut Oil as Oil Phase in Tretinoin Nanoemulsion

ORIGINALITY REPORT

$3 \%$

SIMILARITY INDEX
$2 \%$

INTERNET SOURCES
$2 \%$

PUBLICATIONS
$0 \%$

STUDENT PAPERS

PRIMARY SOURCES

1 repository.unair.ac.id

Internet Source

2 www.ijipsr.com

Internet Source

3 Verma, D.D.. "Particle size of liposomes influences dermal delivery of substances into skin", International Journal of Pharmaceutics, 20030604

Publication

Chien-Fu Liao, Tse-Yen Yang, Yung-Hsiang Chen, Chun-Hsu Yao, Tzong-Der Way, Yueh-

Sheng Chen. "Effects of swimming exercise on nerve regeneration in a rat sciatic nerve transection model", BioMedicine, 2017

Publication 